\title{
Adoption and knowledge level of farmers about alfalfa scientific cultivation practices in Eastern Ladakh (UT), India
}

\author{
Kunzes Angmo*, Sonam Spaldon, Yogesh Kumar, Hanuman L. Verma ${ }^{1}$ Jigmet Laskit $^{1}$, \\ Kunzang Lamo ${ }^{1}$ and M.S. Kanwar \\ High Mountain Arid Agriculture Research Institute, SKUAST-K, Leh Ladakh (U.T.) India
}

\begin{abstract}
Livestock rearing is one of the major occupations of Chanthang region India and is making significant contribution to the Ladakh's socioeconomic development.Important role of alfalfa in development of animal husbandry is based on high potential for production of biomass. The study was conducted in eastern Ladakh (India) during 2015-19, due to deficit and scarcity of fodder crops in the region. First part of the study deals with the agronomic and management techniques adopted for cultivation of alfalfa. Second part deals with the adoption and knowledge level of farmers, which was calculated using a questionnaire. Randomly ten villages were selected from eastern Ladakh, in each village, 10 respondents were randomly selected. The study aimed to assess the adoption and knowledge level of alfalfa growers in alfalfa production. Information was obtained with the help of questionnairemethod. The data were analyzed, tabulated and the results were drawn with the help of descriptive statistical methods. The finding of the study revealed that the overall level of Adoption and knowledge of alfalfa production technology was medium. Majority of the farmers (67\%) had medium level of knowledge and adoption $(60 \%)$ of scientific alfalfa cultivation practices. More number of large farmers had high level of knowledge and adoption as compared to medium and small farmers. More awareness programmes should be organized to increase level of knowledge and adoption of cultivation practices to sustain alfalfa production in eastern Ladakh.
\end{abstract}

Key Words : Knowledge, Adoption, Scientific cultivation practices, Statistical tools, Eastern Ladakh, Changthang

View Point Article : Angmo, Kunzes, Spaldon, Sonam, Kumar, Yogesh, Verma, Hanuman L., Laskit, Jigmet, Lamo, Kunzang and Kanwar, M.S. (2021). Adoption and knowledge level of farmers about alfalfa scientific cultivation practices in Eastern Ladakh (UT), India. Internat. J. agric. Sci., 17 (AAEBSSD) : 98-104, DOI:10.15740/HAS/IJAS/17-AAEBSSD/98-104. Copyright@2021: Hind Agri-Horticultural Society.

Article History : Received : 11.07.2021; Revised : 14.07.2021; Accepted : 18.07.2021

\section{INTRODUCTION}

Livestock rearing is one of the major occupations of the aboriginals of Chanthang region India and is making significant contribution to the Ladakh's socioeconomic development. Animal rearing was mostly based on grazing in the pastures, and feeding systems utilized only locally available resources. However, with the improvement in transportation, people now have the option to purchase fodder from Leh market. The practice of stocking feed for winter has now become most essential for the nomads as the death of livestock due to the scarcity of fodder during heavy snowfall and in winter has become a serious issue over the last few years. In

\footnotetext{
* Author for correspondence :

${ }^{1}$ Krishi Vigyan Kendra, Leh (U.T.) India
} 
2013, more than 22,000 Pashminagoats, yak, and other livestock were killed during unprecedented snowfall in eastern Ladakh due to lack of fodder (Kunzes et al., 2016). The livestock population, over the years, has shown increase on broadly two counts i.e. Increase in the number of stall feeding based bovine livestock viz. Zho,Yaks and cows and also increase in the number of free grazing based livestock (goats and sheep) that can survive on the fast degrading pasturage. The first category of livestock growth pertains to the people with arable land and resources to grow or procure fodder, and forms a good source of additional income for them. The second category of livestock growth on the other hand pertains to millions of resource-starved households, nomadic pastoralists and marginal farmers, for whom livestock rearing often forms the only one and most critical source of food and cash income (Planning Commission of India, 2011). Therefore, animal husbandry sector has a good scope in Eastern Ladakh. However, further growth of the sector will be as much dependent upon the availability of fodder. The available sources reveal that the present fodder availability in the country is well below requirement. It has been observed that only about half of the annual fodder requirement is met from the cultivated fodder and crop residues, whereas open grazing and fodder availability from common property resources like forests, pasturelands, village commons, etc. fulfills the remaining half of the annual fodder requirement. In view of the large number of resource-poor households dependent upon open grazing for their livestock, it is neither desirable nor possible to simply wish away open grazing. So stress is given on the cultivation of the fodder resources in the area. The main cultivated fodder of the area is alfalfa and oats. In India, after sorghum and berseem, alfalfa is the 3rd important fodder crop (Shukla et al., 2016). The total area of Ladakh is $1,18524 \mathrm{~km} 2$ out of which $35,557 \mathrm{~km} 2$ is under Pakistan (30\%) and 11,852 km2 under China (10\%). India occupies an area of 71,114 km2 (60\%) of which 28 per cent is cultivable (Shukla, 1987). Alfalfa is cultivated on an area of 4000 hectares where assured irrigation is available (Anonymous, (2016a). Alfalfa (Medicago spp.) of Ladakh has a long history, (DeCandolle, 1967) designated Ladakh as one of the centre of origin. The local people bear testimony to the fact that it has been the oldest cultivated as well as wild crop of this area. High quality forage for livestock producers or livestock industry means forage with high protein content and high feed consumption is correlated with low fiber and high protein diets. Its economical significance is based on high potential for production of biomass, over $80 \mathrm{tha}^{-1}$ of green and close to $20 \mathrm{t} \mathrm{ha}^{-1}$ of dry matter (Nešiæ et al., 2005, Radoviæ et al., 2004). The alfalfa forages is characterized by a high content of crude protein (Diniæ et al.,2005, Markoviæ et al., 2007a), well balanced with respect to amino acid. It is enrich with vitally important vitamins, and various microelements essential for the normal growth and development of animal (Markoviæ et al., 2007b). Therefore a study was conducted in eastern Ladakh (India) during 2015-19, due to deficit and scarcity of fodder crops in the region. First part of the study deals with the agronomic and management techniques adopted for cultivation of alfalfa. Second part deals with the adoption and knowledge level of farmers, which was calculated using a questionnaire.Attempts to highlight the success stories of our farmer, which is the most needed to combat the fodder scarcity problems in eastern Ladakh.

\section{Material AND Methods}

The study was conducted in Nyoma Block of Ladakh (UT) due to the importance of fodder crops in the areas. The agronomic and management techniques adopted were studied from the earlier study Kunzes, 2021, trial conducted in the study area. To study the knowledge adoption ten villages were randomly selected from three clusters and from every village 10 respondents were selected randomly with total 100 respondents (Table 1). The primary data were collected with the help of questionnaire method during 2018-19. Descriptive Statistical tools were used to analyze the data. The knowledge test consisted of questionnaire covering all the package of practices of alfalfaproduction technology. Total 11 questions were finalized and a scale was developed to measure the knowledge level of farmers and also the adoption level regarding selected technologies recommended for alfalfa crop and was used with due modifications. The responses of respondents regarding knowledge were obtained into three point continuum as,Incomplete knowledge 1; Partial knowledge 2; Complete knowledge 3.

After this adoption index was calculated using following formula: The mean and standard deviation of all the respondents knowledge scores were calculated for classifying the knowledge in different categories. On the basis of mean knowledge score and standard 
deviation the farmers were categorized under three knowledge level categories, namely low, medium and high knowledge level as follows:

Low knowledge level $=$ score up to $($ mean knowledge - S.D. $)$ Medium knowledge level $=$ Score $($ mean knowledge $S . D$. $)$ to (Mean + S.D.)

High knowledge level $=$ Score above $($ mean knowledge + S.D. $)$

Finally the adoption index was calculated by the following formula:

Knowledgeindex : $\frac{\text { Total knowledgescoreobtained by respondents x } 100}{\text { Maximum attainablescore }}$

The formula was applied for all practices which helped in calculating adoption index. The mean and standard deviation of all the respondents adoption scores were computed for classifying the adoption in different categories. Based on the mean adoption score and standard deviation. The farmers were categorized under three adoption level categories, namely low, medium and high adoption level as follows:

Low adoption level $=$ Score up to $($ mean adoption - SD)

Medium adoption level $=$ Score from $($ mean adoption-SD)

to $($ Mean + SD)

High adoption level $=$ Score above $($ mean adoption + SD)

\section{RESUlts AND DisCussion}

The results obtained from the present investigation as well as relevant discussion have been summarized under following heads :

\section{Alfalfa cultivation:}

Medicago sativa Linn.,is known as the "Queen of the Forages" and is grown globally as one of the important (Michaud et al., 1988) and nutritious fodder crop. It belongs to the family fabaceae and occurs widely in the Caucasian region and in the mountainous regions of Iran, Afghanistan and adjacent localities. The species is known to be originated in Persia, latter, spread to many other countries. It has a high forage yield potential, and can produce these high yields without nitrogen fertilization. Furthermore, alfalfa is high in digestible energy and protein, makes it an extremely valuable feed.Alfalfa is a versatile crop that can be used for pasture, or as hay, silage, or green-chop in Ladakh. As a result of its versatility, yield potential, and quality, alfalfa can be used successfully in many types of livestock feeding programs. Consequently, it is highly sought after and can be a profitable cash crop for Ladakh. It can also play an important role in crop rotations since it supplies substantial amounts of organic nitrogen to subsequent crops and has numerous other positive effects on soil fertility, soil structure, and soil health.Alfalfa is not a new crop in the Ladakh, It has been grown in the region since the late 1900's and continues to be recognized as a excellent forage species. However, to date alfalfa has not attained the status in the Changthang that it has in other parts of the Ladakh. Like other regions, alfalfa acreage moved slowly upward for several decades in the early 1900's. Then, it was further spread for the cultivation in Eastern Ladakh.

\section{Agronomic and management techniques adopted:} Site selection:

The most important requirement for alfalfa cultivation is sites selection. The site should be fenced and should have source of water. The land requirement for alfalfa growth is a deep, well-drained, loamy soil where $\mathrm{pH}$ varies between 6.5 and 7.5 for optimum production. Root rot diseases and winter heaving damage are greater on poorly drained than on well-drained sites. The area should be free of hardpans and shallow bedrock, to accommodate the plant's long taproot system.

\section{Soil testing and fertilizing:}

Before going for cultural practice, soil testing is the most important step for checking the alfalfa fertility status and application. The test will be used as a guide to determine application rates of lime, phosphorus, and potassium. It responds well in the areas with phosphorus and potassium fertility, but no nitrogen is required, since alfalfa, being a legume fixes its own nitrogen. It also uses $1-2.5 \mathrm{~kg}$ of boron per acre per year. Adequate lime, phosphorus, and potassium levels should be established prior to planting, if possible. Base fertilizer application rates on soil-test results, crop needs, and the nutrient content of the material being applied. After the crop is established, only surface applications will be possible. Wet soils can cause root heaving during winter and cause more problems with root diseases than well-drained soils. Best time to lime and fertilize the stand is after the last harvest of the growing season and before growth begins the next growing season. In sandy soils, one-half of the annual potassium fertilizer should be applied after the second cutting of the growing season. . In an organic system, soil fertility can be maintained with mineralbearing rock powders such as rock phosphate and with animal manures, compost, and vermin-compost. Animal manure can provide both phosphorus and potassium economically. It is beneficial to base manure and compost 
rates on soil test nutrient levels, the nutrient content of the manure, and crop needs.

\section{Seeding and spacing:}

The rate of seeding ranges from $1.5 \mathrm{~kg}$ per kanal or $20 \mathrm{~kg}-25 \mathrm{~kg}$ per hectare in Changthang region. The method of sowing is mainly broadcast into a wellprepared land. Seeds have hard coat and they were soaked in water before sowing. There should be firm seed-to-soil contact. Basically, the seed bed can be tested by walking off with your shoes, if sink into the prepared soil past the soles, that too shows the need for a firmer seedbed. Seed must not be planted too deep. In case of Spacing, experimentally it was grown with spacing combinations $60 \times 30 \mathrm{~cm}$ and has resulted best growth, as plants being much taller with more branches, full of Flowers and pods.

\section{Growth and development:}

Sowing of alfalfa can be done throughout the year depending on the environmental conditions, availability of soil moisture and frost occurrence. In Changthang region sowing is mostly done in late spring or beginning of summer.It has been seen earlier sowing date in spring, the higher production in the following spring (justes et al., 2002). Timing and germination rate depends on the temperature, moisture condition, soil salinity and depth of the seed sown. Once the crop is established, the longevity depends mainly on the plant population, climate and stand management. The initial plantpopulation determined by sowing and emergence rates, progressively selfthins and consequently the population declines. Alfalfa is long day plant and reachesreproductive stages (characterized by the appearance of floral buds) faster during summer when the days are long, whereas the vegetative stage is extended when the days are short in late summer and autumn. After emergence in seedling stage,growth and development is slower than during regrowth. This is because seedlings lacks a mature root system, nodulated and preferentially accumulate carbon and nitrogen reserves in perennial organs during this early stage. The seedling crop goes through a juvenile period of vegetative growth when development is insensitive to daylength and flowering is delayed relative to re-growth crops (Teixeira et al., 2011).

\section{Harvesting for quality:}

Alfalfa, is used as hay in the region. Climate-based recommendations for harvest dates and schedules vary within district. Additionally, these recommendations may need to be changed to meet yield, forage quality, and stand persistence goals.

The harvesting of alfalfa depends on the climatic condition of the area. After harvesting which is mostly done in other parts of Ladakh, new cohort of vegetative shoots is generated. The duration from the initiation of new shoots to the reproductive stage may be modified by the day length and temperature. The response to the day length differs with the cultivar and is more pronounced at high altitudes. After the floral initiation, temperatures alone will drive the development through flowering, seed filling and maturity. Temperature above $27 \mathrm{c}$, water stress or excessive soil moisture condition can decrease seed yields. The main factor determining the growth of alfalfa is rate of biomass accumulation is the amount of carbon assimilated through photosynthesis, which depends on the light intercepted by the canopy. It survives in winter by storing carbon and nitrogen compounds as reserves. The reserves are than used to resume growth during the following spring and after each harvest (Avice et al., 1977), Nitrogen and carbon are mobilized to form new leaves and stems while carbon is also respired to supply energy to sustain root metabolic activities. The portioning of assimilated carbon to the crown and taproot is seasonal.

During the spring, biomass is retained in the shoots and less than $5-15 \%$ is partitioned below ground. High altitude cultivarsresponse has a more evident seasonality with higher biomass portioning to root in late summer and autumn in response to lower temperature and shorter. The ultimate test of forage quality is animal performance. Forage must be palatable (readily consumed by animals) in addition to containing sufficient energy and protein. Research and farmer experience have shown alfalfa to be a superior feed that is readily consumed. In fact, high quality alfalfa may actually stimulate intake by livestock that are consuming low quality forages. Alfalfa is one of the best rotational crops having soil conditioning abilities. Apart from its perennial nature, it provides congenial environment forbeneficial arthropods, includes pollinators and natural enemies of pests, which will keep the pest levels low in alfalfa.

\section{Success story:}

Success story of an alfalfa Farmer Tsering Angmo w/o Chemet Dorjey, (age 46years) of village Nidder, block 
Nyoma, Post Office, Nyoma, district Leh, Pin 194101) is a progressive farmer of her village and locality. She had opted agriculture occupation for her livelihood and when KVK Nyoma had provided her with seeds and technical knowhow on alfalfa, she agreed to grow fodder as one of the crops in her field. She has a family member of 6 and her husband is a porter. Together, they own 6 kanals of Land. She belongs to the semi-nomadic community and owns 10 goats and 3 sheep, 2 cows, 4 horses and a yak. So the need for the fodder and scarcity had convinced her to grow alfalfa in her 1 kanal ( 0.0054 hac) lands which was otherwise kept fallow. Traditionally she grows barley, mustard and oats as field crops apart from growing some vegetables. She was convinced about the profitability of alfalfa cultivation; she decided to grow this crop under the supervision of Dr Kunzes Angmo (SMS Rangel and/Ecology).After a year of cultivation, she could get a good amount of profit and yield. Seed was extra bonus for herself. The produce wasused for livestock and was not dependent on the government subsides. She harvested the crop after three months and received a bumper crop of 1 ton $25 \mathrm{~kg}$ from her land. In the same year she got the best on farm crop producer at KVK, Nyoma Kissanmela 2018.

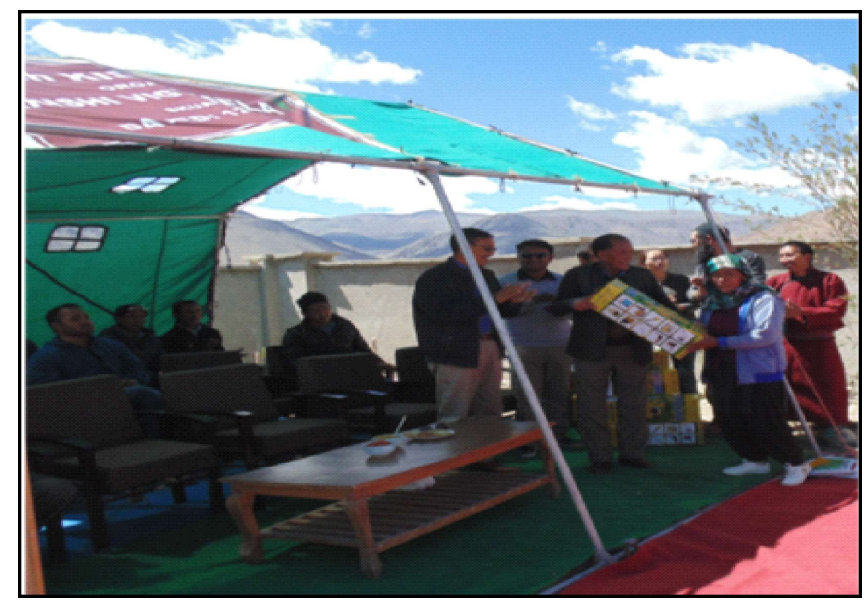

Fig. 1: KVK, Nyoma "Kisan Mela 2018"

\section{Outcomes and impact:}

Socio-economic upliftment of Changpa herders. Rejuvenation of native pastures lands for sustainable livestock production. Restoration of fallow and barren waste lands through cultivation of alfalfa. Fodder management innovations programme for Changthang valley (private land and community land use for improving fodder production and supply) by KVK, Nyoma
SKUAST was a successful event and it was horizontally expanded in their own village and nearby villages (Mudh, Nyoma, Mahe, Loma, Rongo). In future this shall create a repository of fodder at local level. Communities are growing forages in impossible places and strengthening their livelihood with new options of low-cost dietary diversity and expanded sources of income with the help of farm science centers.

\section{Practice wise knowledge:}

After the successful production of alfalfa in eastern Ladakh. It was pertinent to know the expansion of the technology in the area. Therefore, practice wise knowledge was studied to analyze the impact of the crop. Total ten villages were selected from block Nyoma Table 1.

\begin{tabular}{lll}
\hline \multicolumn{2}{l}{ Table 1:Villages selected for practice wise knowledge Nyoma, Block } \\
\hline Village & Cluster & Lifestyle \\
\hline Nidder & Cluster I & Semi-nomadic \\
Mudh & Cluster I & Semi-nomadic \\
Nyoma & Cluster I & Semi-nomadic \\
Mahe & Cluster I & Semi-nomadic \\
Hanley Punguk & Cluster II & Semi-nomadic \\
Hanley Naga & Cluster II & Semi-nomadic \\
Liktse & Cluster III & Sedentary \\
Tukla & Cluster III & Sedentary \\
Hemiya & Cluster III & Sedentary \\
Kungyam & Cluster III & Sedentary \\
\hline
\end{tabular}

Table 2, Indicated that, the average knowledge extent of farmers about scientific cultivation of alfalfa in eastern Ladakh was37.54 per cent whereas, extent of adoption of recommended scientific alfalfa cultivation practices were 33.1 per cent.

Out of 11 selected cultivation practices, the extent of knowledge of "Harvesting" $65 \%$ was higher than the other practices of alfalfa followed by "field preparation", $60 \%$, and "Time of sowing" $54 \%$ and "marketing" $50 \%$ were ranked $3 \mathrm{rd}$ and $4^{\text {th }}$, respectively. Regarding recommended knowledge extent of scientific alfalfa cultivation practices like, "Irrigation management" "Rate of Sowing of Seed" and "Row to Row distance"had $47 \%, 37 \%, 32 \%$ and ranked $5^{\text {th }}, 6^{\text {th }}$ and $7^{\text {th }}$, respectively. While the extent knowledge of recommended scientific alfalfa cultivation practices likes,", "Plant Spacing", and "weeding" with $28 \%$ and $20 \%$ and were ranked, $8^{\text {th }}$ and $9^{\text {th }}$, respectively. Further, the knowledge extent of 
Kunzes Angmo, Sonam Spaldon, Yogesh Kumar, Hanuman L. Verma, Jigmet Laskit, Kunzang Lamo and MS Kanwar

recommended scientific alfalfa cultivation practices likes, "fertilization" and varieties of alfalfa" had $17 \%$ and $3 \%$ with $10^{\text {th }}$ and $11^{\text {th }}$ ranked, respectively.

The same questionnaire was used for the knowledge adoption among the same number of informants. In case of extent of adoption "Time of sowing", 64 percent was higher than the other adopted practices of alfalfa and it was ranked 1 stfollowed by the adoption of "Harvesting "and"Rate of sowing" 57 per cent, 42 per cent and were ranked $2^{\text {nd }}$ and 3 rd, respectively. The extent of adoption of the recommended scientific alfalfa cultivation practices like "Field Preparation" 41 per cent "Irrigation management" 39\%"varieties " 38 per centand "Marketing" 36per cent and were ranked $4^{\text {th }}, 5^{\text {th }} 6^{\text {th }}$ and $7^{\text {th }}$ respectively. While the extent adoption of recommended scientific alfalfa cultivation practices likes "plant spacing", "Row to Row distance" and "fertilization" and "weed management", with 21 per cent, 18 per cent and 6 per cent and 2.00 per cent and ranked $8^{\text {th }}, 9^{\text {th }} 10^{\text {th }}$ and $11^{\text {th }}$, respectively.

The Data in Table 3. Indicated that majority of the respondents $(67.00 \%)$ had medium level knowledge followed high $(21.00 \%)$ and low $(12.00 \%)$ level knowledge about scientific alfalfa cultivation practices respectively. Whereas in case of adoption $60 \%$ had medium level adopted the scientific cultivation method Thus, it may be concluded that majority of respondents (67\%) were found medium level (23-44) knowledge about scientific alfalfa cultivation practices. The Data indicated that majority of the respondents of about 60 per cent of farmers were found to be medium adoption, while 25 per cent farmers were high adoption and 15 per cent farmers were low adoption level.

\section{Conclusion:}

According to the study result Medicago sativa being the herbaceous perennial legume has significant advantage than growing oats solely in the fallow lands increasing the DM yield harvested. Among the tested legume alfalfa was found to be the best legume in Lower regions of the eastern Ladakh especially, Liktsey, Tukla, Nee, Kumdok, till Nidder . But the germination percent was very low in the upper villages of Hanley, Demchok and Kuyul especially above $4600 \mathrm{~m}$ elevations. Therefore, from this study we recommend that Medicago sativa was found to be the best forage species both in terms of storage and adaptability with low benefit cost ratio in regions between $3200-4200 \mathrm{~m}$. However, in other higher regions species of Oats can be cultivated in Eastern Ladakh.

Majority of the farmers had medium level of knowledge and adoption of scientific alfalfa cultivation. The large farmers had comparatively higher level of knowledge and adoption about scientific cultivation of alfalfa than the medium and small farmers. The extension agencies have to play an important role to create awareness among the farmers about scientific alfalfa cultivation practices. Krishi Vigyan Kendra should demonstrate to the farmers on importance of fertilization and weeding as other cash crops and keep them updated about recent HYVs. Government should ensure farmers timely availability of quality seeds and procurement of

\begin{tabular}{|c|c|c|c|c|c|}
\hline \multirow{2}{*}{ Sr. No. } & \multirow{2}{*}{ Cultivation practices } & \multicolumn{2}{|c|}{ Knowledge } & \multicolumn{2}{|c|}{ Adoption } \\
\hline & & Percentage & Rank & Percentage & Rank \\
\hline 1. & Field preparation & 60 & II & 41 & IV \\
\hline 2. & Varieties of alfalfa & 3 & XI & 38 & VI \\
\hline 3. & Time of sowing & 54 & III & 64 & I \\
\hline 4. & Rate of sowing of seed per kanal & 37 & VI & 42 & III \\
\hline 5. & Row to row distance & 32 & VII & 18 & IX \\
\hline 6. & Plant spacing & 28 & VIII & 21 & VIII \\
\hline 7. & Irrigation management & 47 & V & 39 & V \\
\hline 8. & Fertilization & 17 & $\mathrm{X}$ & 6 & $\mathrm{X}$ \\
\hline 9. & Weeding & 20 & IX & 2 & XI \\
\hline 10. & Harvesting & 65 & I & 57 & II \\
\hline \multirow[t]{2}{*}{11.} & Marketing & 50 & IV & 36 & VII \\
\hline & Total average & 37.54 & & 33.1 & \\
\hline
\end{tabular}


farm produce at reasonable price. It has been observed that alfalfa is the solution for the scarcity of fodder in eastern Ladakh.This sustainable fodder legume can address these constraints, because of its perennial nature and also have the potential to produce higher total dry matter yield with better herbage quality through suppressing weed growth and improving thefertility insoil.

\section{REFERENCES}

Anonymous, (2016a). United Nation Food and Agriculture Organization, pp. 56.

Candolle, A. (2011). The origin of cultivated plants. 10.1017/ CBO9781139107365.

Diniæ B., Đorðeviæ N., Radoviæ J., Ignjatoviæ S. (2005). Modern procedures in technology of conserving lucerne in ensiling. Biotechnology in Animal Husbandry, 21 (5-6): $297-$ 303.

Kunzes Angmo, Maheshwar Singh Kanwar, Rukhsar Ahamad Dar, and Gopal Singh Rawat (2012). Recent Changes in Yak Herding Practices in Eastern Ladakh and Implications for Local Livelihoods. Yak on the move. ICMOD.

Markoviæ J., Radoviæ J., Lugiæ Z., Sokoloviæ D. (2007a). The effect of development stage on chemical composition of alfalfa leaf and steam. Biotechnology in Animal Husbandry, 23 (5-6): Book 2, 383-388.

Markoviæ J., Ignjatoviæ S., Radoviæ J., Lugiæ Z. (2007b).
Uticaj faze razviæa na sadržaj makro i mikroelemenata u lucerki i crvenoj detelini. Zbornik radova, Institut za ratarstvo i povrtarstvo, Novi Sad, 44 (1): 401-406.

Michaud,R., Lehman,W.F and Rumbaugh, M. D. (1988). Feeding value (Forage quality).In:Hanson, AA., Barnes, D.K \&Hill, R.R., J reds. Alfaalfa and alfalfa improvement. Madison, Wiscosin: American Society of Agronomy, Inc., crop Science Scciety of America, Inc, Soil Sciene society of America, Inc, 29: 25-91.

Misri, B. (1987). Disjunct distribution of Avenafatua as a weed in Ladakh. Oat News Letter, pp. 37.

Nešiæ Z., Tomiæ Z., Žujoviæ M., Krnjaja V. (2005). Production characteristics of domestic alfalfa (Medicago sativa L.) cultivars in agro ecological conditions of Srem district. Biotechnology in Animal Husbandry, 21 (5-6) 169-173.

Planning Commission of India (2011). Report of the Sub Group III on Fodder and Pasture Management, 2011.Constituted under the Working Group on Forestry and Sustainable Natural Resource Management. Version:1.5 (21 September).

Radoviæ J., Lugiæ Z., Ignjatoviæ S., Deliæ D. (2004). Prinos i kvalitet suve materije genotipova lucerke (Medicago sativa L.) razlièitog porekla. Acta Agriculturae Serbica, 9 (17): 109114. Alfalfa - most important perennial forage.

Shukla, G.P., Tripathi, S.N. and Natrajan, S. (2016). Crop profile of Lucerne. Crop Science, 9: 83.

$16_{\text {Year }}^{\text {th }}$

$\star \star \star \star \star$ of Excellence $\star \star \star \star \star$ 